\title{
Analysis on the Present Situation and the Countermeasures of the Construction of Counselors in Private Colleges and Universities
}

\author{
Cai Liang ${ }^{1}$, Zhou Qinghua ${ }^{2}$, Dang Huimin ${ }^{3}$, Li Danxia ${ }^{4}$ \\ ${ }^{1,2,3,4}$ Xi'an Peihua University, Xi'an Shaanxi Province, 710125
}

Keywords: private colleges and universities; counselors; team building; career planning; motivation mechanism

\begin{abstract}
With the expansion of colleges and universities, private colleges and universities have been developed rapidly, but the ideological and political education of private college students in the new period is more difficult, so it is necessary to attach importance to the function and role of counselors. However, it is difficult to meet the needs of the transformation and development of private colleges and universities in the current situation, the ability and quality of counselors need to be continuously improved, and the construction of counselors should be strengthened. In this paper, the current situation of counselors in private colleges and universities, and the problems of counselors in private colleges and universities are diagnosed. Finally, the countermeasures of counselors' team construction in private colleges and universities are explored.
\end{abstract}

\section{Introduction}

Counselors are teachers engaged in ideological and political education, daily management of students, employment guidance, mental health and the construction of students' party groups. Each counselor generally manages one or more classes. The counselors help college students to set up correct world outlook, life outlook and values, to establish the socialist road with Chinese characteristics under the leadership of the Communist Party of China, and to realize the common ideal and firm belief of the great rejuvenation of the Chinese nation. To actively guide students to pursue higher goals, so that the advanced elements of them set up the lofty ideal of communism, and establish the firm faith of Marxism. To help college students develop good moral qualities, to carry out regular heart-to-heart talk activities, to guide students to develop good psychological qualities and good self-respect, self-love, self-discipline, self-improvement, and to strengthen students' good character in overcoming difficulties and withstanding tests. The ability to withstand setbacks, to help students deal well with the specific problems of learning, making friends, making friends and living healthily, to improve their ideological understanding and spiritual state, and to understand and master the ideological and political situation of college students. Aiming at hot spots and focus issues of concern to students, timely education and guidance should be carried out to resolve contradictions and conflicts, participate in handling related emergencies, maintain campus safety and stability, and counselors should carry out the relevant work related to financial assistance to students with financial difficulties. Organizing college students' part-time study, actively helping students with financial difficulties to complete their studies, actively carrying out employment guidance and service work, providing students with efficient and high-quality employment guidance and information services, and helping students to establish correct employment concepts; Take the class as the foundation, take the student as the main body, give play to the organization strength of the student class collective in the ideological and political education of the university students, organize and coordinate the class teacher, The backbone of the ideological and political theory course teachers and organization members should do a good job of regular ideological and political work, carry out various forms of educational activities among the students, guide the construction of the students' party branches and class committees, and do a good job in cultivating the backbone of the students. Stimulate students' enthusiasm and initiative. 


\section{Current Situation of Counselors in Private Colleges and Universities}

The team analysis of counselors in private colleges is mainly analyzed from the aspects of specialty, educational background structure, age structure and professional technical structure.

In the course of the development of private colleges and universities, the important channel of counselors is to admit students to stay in schools. Through investigation, it is found that nearly $60 \%$ of counselors in private colleges are students who stay in school, and there is a certain phenomenon of "inbreeding". At the same time, private college students studying in the same professional background and ideological and political education, education management. The professional level of counselors in private colleges and universities needs to be improved.

Counselors in private colleges and universities are gradually introducing highly qualified personnel, but in the current team of counselors, undergraduate education still occupies a dominant position. According to the survey, Counselors in private colleges and universities occupy 70 undergraduate degrees, graduate degrees only account for 15, doctorate counselors, and even some counselors are specialized qualifications. It can be seen that the educational structure of counselors in private colleges and universities needs to be optimized, and it is urgent to introduce high-level qualified personnel into the counselors' ranks.

Due to the introduction of private college counselors are basically fresh graduates, private college counselors tend to be younger. According to the result of the investigation, the counselors whose age is about 30 years old or less than 30 years old, accounting for $85 \%$ of the counselors aged 30 to 40 years old, and the counselors who are between 40 and 55 years old, occupying $7 \%$ of the counselors, and the average age of the counselors as a whole is on the low side. The age structure of counselors in private colleges and universities needs to be optimized, mainly for the young and middle-aged, and for the old and the new to promote the growth and development of counselors.

Due to the younger counselors in private colleges and universities, the promotion time of counselors' professional titles is too short. At the same time, because the counselors in private universities are busy with their daily affairs, it is difficult to find self-improvement, and the rate of scientific research results is low, unable to meet the requirements for promotion of a higher professional title. Therefore, the titles of counselors in private colleges and universities are mainly "nil" and "primary titles", a few counselors have intermediate titles, and there are almost no counselors with senior titles. Thus, private college counselors need to speed up the promotion of professional titles.

\section{The Problems of Counselors in Private Colleges and Universities}

According to the above mentioned, there are many problems in the team of counselors in private colleges and universities:

Private college counselors introduce a single channel, leaving too many students, resulting in inbreeding, the ability of innovation hindered; private college counselors are too young, title structure to be optimized, senior professional counselors lack, the construction of counselors is short of gradient and powerful leader, so it is difficult to form the effect of spreading help. There are many daily affairs for counselors in private colleges and universities, so it is difficult to find time for self-study and promotion.

The counselors in private colleges and universities are not strong in team building, lack of unified strategic goals and mission support, initiative, enthusiasm and creativity in their work, and lack of professional complementarity among counselors. The project research ability of counselors in private colleges is weak and it is difficult to produce high level academic achievements. There are few opportunities for sharing and exchanging among counselors in private colleges and universities, and team building needs to be strengthened.

The professional level of counselors in private colleges is relatively low, and the knowledge structure is relatively simple. In the era of knowledge economy, counselors in private colleges need to have professional knowledge of ideological and political education, but most counselors in 
private universities are students who stay in schools, with a relatively low level of academic qualifications and a relatively simple knowledge structure. Most of them are not major of ideological and political education, lack of professional knowledge of scientific management, consultation of mental health education and professional skills of ideological and political education, and the ability of political situation analysis is relatively poor. The professional level of ideological and political education of counselors in private colleges must be improved.

Due to the backward construction of the incentive system for counselors in private colleges and universities, the poor professional identity of counselors in private colleges and universities, and insufficient incentive management for counselors, this has affected the enthusiasm, initiative and creativity of counselors in private colleges and universities.

In addition, there are many problems in the construction of counselors in private colleges and universities, such as the lack of understanding of the importance of counselors in private colleges and universities, and the relatively low status of counselors in private colleges and universities; The counselors of private colleges and universities are not clear about their own position, lack of status identity and professional identity; private colleges and universities for counselors of the various management system is not standardized, each management mechanism needs to be innovated.

\section{Countermeasures for the Construction of the Team of Counselors in Private Colleges and Universities}

In the construction of counselors in private colleges and universities, we should improve the professional ethics of counselors, pay attention to their scientific research ability, attach importance to the team cooperation of counselors, strengthen the career planning of counselors, and improve the incentive mechanism of counselors.

It is a long-term systematic project for counselors to promote their professional ethics in students' ideological and political work. Private colleges and universities need to provide more training opportunities for counselors to enhance their professional ethics; counselors themselves need to strengthen their learning; counselors can use network means and network resources through training courses organized by the state and universities, as well as comprehensive use of network means and resources. To improve their own ideological and political awareness, and in real life can achieve patriotic law-abiding, dedication and love for students, education for the people, lifelong learning, role models, the counselors of private colleges and universities can truly become the life mentors and confidant friends of young students and win the trust and respect of the students and the recognition of the society.

Counselors in private colleges and universities need to effectively enhance their own scientific research ability, strengthen the theoretical basis of ideological and political education work, and be good at using advanced ideas, views and methods to understand problems. Counselors also need to improve their job-related knowledge of pedagogy, psychology, sociology, management, and so on, improve the theoretical basis of student work, familiarize themselves with basic research and applied research of student work, the basic knowledge of decision consultation and investigation, improving working methods, improving the pertinence and effectiveness of work.

Private colleges and universities need to attach importance to the cultivation of core talents and the rational flow and optimization of talents in the construction of counselors' team, and fully mobilize their enthusiasm and creativity in order to provide conditions for the innovation of counselors' brand team in private colleges and universities. Effective team cooperation is an effective factor to create the brand of counselors in private colleges and universities. Enhance counselors' professional identity, sense of honor and sense of belonging. At the same time, private colleges and universities need quality expansion activities, salon sharing meeting and other activities to enrich the team culture of counselors, enhance the cohesion of private college counselors team an important platform.

Private colleges and universities need to strengthen the career planning of counselors, first of all, self-analysis, career analysis, self-career positioning, and respectively establish six months, one year, three years, and five years plan. Make detailed short-term and long-term plan respectively: 
short-term detailed plan: this term to let the class pass the examination rate to achieve percentage points, how to do ideological work and help students successfully pass the exam. Provide students with career guidance, career guidance, and career prospect planning. 2) Long-term detailed plan: establish a long-term public platform. For example: annual Entrepreneurial Innovation Competition, Financial platform for Poor students, Student Sports Club, etc.) to improve their own quality: improve their political quality, moral level, improve their ability to manage and organize, Train oneself good expression ability, study psychology knowledge. Private colleges and universities should give counselors a wide range of career prospects.

Private colleges and universities need to improve the initiative, enthusiasm and creativity of counselors, establish and improve the incentive mechanism of counselors, establish a sound incentive mechanism for the professional development of counselors, and establish the training and training system of counselors. Establish a sound compensation management system and a scientific and effective performance management system. This is also directly related to the effect of ideological and political education in private colleges and universities. It is helpful to strengthen the management of counselors in private colleges and universities to achieve a high-quality team of counselors and improve the efficiency of work for counselors, promoting ideological and political education in private colleges and universities to a new level.

\section{Conclusion}

In a word, there is a long way to go in the construction of counselors in private colleges and universities. Private colleges and universities should further increase investment in the construction of counselors, optimize the working environment of counselors, and strengthen humanistic care for counselors. Attach importance to the psychological management and emotional management of counselors, enhance the sense of belonging of counselors, constantly improve the self-ability and quality of counselors, attach importance to the team building of counselors, attach importance to the incentive mechanism of counselors, and then improve the work efficiency of counselors, in order to achieve a win-win situation between private colleges and counselors.

\section{Acknowledgment}

This article belongs to the stage achievement of Xi'an Peihua University's special project of Xi'an Social Science Foundation in 2016. Project Name: "Analysis of the Current Situation of Counselors in Private Colleges and Countermeasures for Construction-based on an Empirical Investigation of Private Universities in Shaanxi Province"(No. 16PH02)

\section{References}

[1] Wang Xue. Study on the status quo and Strategy of Counsellor team Construction in Private Universities [J]. Journal of Shandong College of Excellence

[2] He Kui. On the professionalization of counselors in private colleges and universities [J]. Education and Teaching Research:38-40.

[3] Wang Jiulong, Fan Jiagun, Zou Xiaohui. The Construction of College counselors' Professional ability Model [J]. Education and Teaching Forum, 2017 28: 25-27.

[4] Wang Xin. On the realization of the value of counselors in Private Colleges and Universities in the New era [J]. Journal of Jilin Radio and Television University, 2018.

[5] China Yuan Jing. The way of Professional Development of College counselors: from the Perspective of counselors' Professional competence Standard [J]. To Know and Do, 2017(10): 108-112. 